\title{
Monitoring glacial thickness changes in the Tibetan Plateau derived from ICESat data
}

- Phan Hien Vu ${ }^{1}$

- Roderik Lindenbergh ${ }^{2}$

- Massimo Menenti ${ }^{2}$

${ }^{1}$ Ho Chi Minh city University of Technology,VNU-HCM, Vietnam

${ }^{2}$ Delft University of Technology, The Netherlands

(Manuscript Received on June $28^{\text {th }}$, 2016, Manuscript Revised August 18 ${ }^{\text {rd }}$, 2016)

\begin{abstract}
Monitoring glacier changes is essential for model (DEM) and the Global Land Ice estimating the water mass balance of the Tibetan Plateau. Recent research indicates that glaciers at individual regions on the Tibetan Plateau and surroundings are shrinking and thinning during the last decades. Studies considering large regions often ignored however the impact of locally varying weather conditions and terrain characteristics on glacial evolution, i.e. the impact of orographic precipitation and variation in solar radiation. Our hypothesis is therefore that adjacent glaciers of opposite orientation change in a different way. In this study, we exploit Ice Cloud and land Elevation Satellite (ICESat)/ Geoscience Laser Altimetry System (GLAS) data in combination with the NASA Shuttle Radar Measurements from Space (GLIMS) glacier mask to estimate glacial thickness change trends between 2003 and 2009 on the whole Tibetan Plateau. The results show that 90 glacial areas could be distinguished. Most of observed glacial areas on the Tibetan Plateau are thinning, except for some glaciers in the Northwest. In general, glacial elevations on the whole Tibetan Plateau decreased at an average rate of $-0.17 \pm$ 0.47 meters per year ( $m$ a-1) between 2003 and 2009, taking together glaciers of any size, distribution, and location of the observed glacial area. Moreover, the results show that glacial elevation changes indeed strongly depend on the relative position in a mountain range.
\end{abstract} Topographic Mission (SRTM) digital elevation

Keywords: Tibetan Plateau, glacial change, ICESat/GLAS, SRTM DEM, GLIMS

\section{INTRODUCTION}

The Tibetan Plateau has steep and rough terrain and contains $\sim 37,000$ glaciers, occupying an area of $\sim 56,560 \mathrm{~km}^{2}(\mathrm{Li}, 2003)$. Recent studies report that the glaciers have been retreating significantly in the last decades. These studies were in different parts of the Tibetan Plateau, such as the Himalayas (excluding the Karakoram) (Yao et al., 2012), the Tien Shan Mountains (Sorg et al., 2012), the Middle Qilian

\section{Trang BO}


Mountain Region (Wang et al., 2011; Tian et al., 2014), the western Nyaiqentanglha Range (Bolch et al., 2010), the inner Tibetan Plateau (Zhang et al., 2008; Wei et al., 2014), and the Mt. Everest region (Ye et al., 2009). Most of the above results were analyzed from topographic maps, in situ measurements, and optical remotely sensed images during the observed periods. Additionally, based on the ICESat/GLAS data and a DEM, Kaab et al. (2012) quantified the glacial thinning in the Hindu Kush-Karakoram-Himalaya region, Kropacek et al. (2013) estimated volume changes of the Aletsch Glacier in the Swiss Alps, and Gardner et al. (2013) estimated thickness change rates for high-mountain Asian glaciers. Moreover, Neckel et al. (2014) applied a method similar to Kaab et al. (2012) for estimating glacier mass changes at eight glacial sub-regions on the Tibetan Plateau between 2003 and 2009.

The results indicated that most of the glacial sub-regions had a negative trend in glacial thickness change, excluding one subregion in the western Mt. Kunlun in the Northwest of the Tibetan Plateau. However, sampled glacial sub-regions were relative large. As a consequence, the glacial conditions were not homogeneous, due to e.g. orographic precipitation and variation in solar radiation. The significant influence of climatic parameters (Bolch et al., 2010) and spatial variability (Quincey et al., 2009) on glacial change rates has already been demonstrated for several individual glaciers on the Tibetan Plateau. In addition, the quality of ICESat elevations is known to be strongly dependent on terrain characteristics. Therefore, this study exploits ICESat/GLAS data for monitoring glacial thickness changes on the whole Tibetan Plateau, identifying sampled glacial areas based on ICESat footprints and glacier orientation. In addition, we explore the ICESat/GLAS data by applying criteria impacting the quality of footprints including acquisition condition and terrain surface characteristics.

\section{DATA AND METHODS}

\subsection{Input data}

The input data sources consist of the ICESat GLA14 land surface elevation data (Zwally et al., 2011), the SRTM DEM (Jarvis et al., 2008), and the GLIMS glacier mask (Li, 2003). Figure 1 illustrates the SRTM elevations, GLIMS glacier outlines and ICESat L2D campaign tracks on the Tibetan Plateau. The geo-location of each ICESat footprint is referenced to WGS84 in horizontal and to EMG2008 in vertical. Each GLIMS glacier is represented by a polygonal vector and is referenced to the WGS84 datum. The SRTM DEM has a resolution of $90 \mathrm{~m}$ at the equator corresponding to 3 -arc seconds and is projected in a Geographic (latitude / longitude) projection, with the WGS84 horizontal datum and the EGM96 vertical datum. The vertical error of the SRTM DEM's is reported to be less than $5 \mathrm{~m}$ on relative flat areas and $16 \mathrm{~m}$ on steep and rough areas (Zandbergen, 2008). In addition, based on the SRTM DEM, the terrain surface parameters slope $\mathrm{S}$ and roughness $\mathrm{R}$ are estimated, using a $3 \times 3$ kernel scanning over all pixels of the grid (Verdin et al., 2007) and (Lay, 2003), where the width and the height of a grid cell in meters are computed, following to Sinnott (1984).

\subsection{Methods}

To estimate a glacial thickness change trend, we consider differences between glacial surface elevations derived from 2003 - 2009 ICESat laser altimetry and a digital elevation model. Here the digital elevation model is used as a reference surface. In addition, a glacier mask is used to identify ICESat elevations that are likely to sample glaciers. 


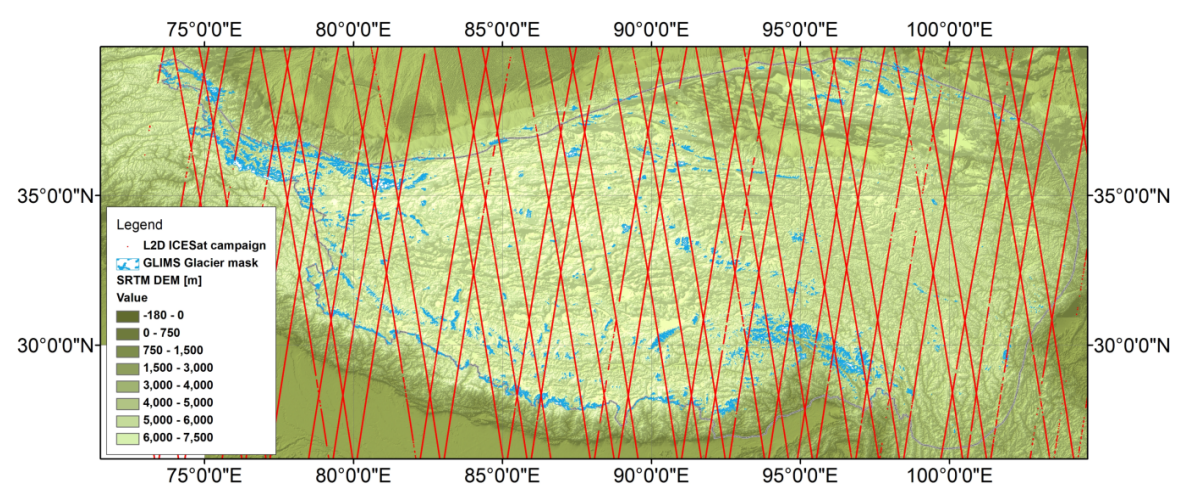

Figure 1. GLIMS glacier outlines and ICESat L2D-campaign tracks superimposed on the SRTM DEM over the Tibetan Plateau

Each difference is time-stamped by the ICESat acquisition time. Valid differences obtained during the same ICESat campaign track over a certain homogeneous glacial area, also called a sampled glacial area, are used to estimate a mean difference. Mean differences for each sampled glacial area are grouped to form a time series. Consecutively, a temporal trend is estimated through the mean differences per area, resulting in a temporal trend of glacial thickening or thinning.

a) Determining a sampled glacial area: footprints of all ICESat campaigns within the GLIMS glacier outlines were extracted, as illustrated in Figure 2. For example, in Figure 2 the ICESat-sampled glaciers having a northern orientation were grouped into one glacial area, A, while those on the other side of the mountain ridge were grouped into another glacial area, B.

b) Identifying a glacial elevation difference: A glacial elevation difference $\Delta \mathrm{h}$ is identified as the difference between an elevation of an ICESat footprint within a sampled glacial area and the reference SRTM DEM, where $\Delta \mathrm{h}=$ $\mathrm{h}_{\text {ICESat }}-\mathrm{h}_{\text {SRTM }}$ is in meters above EGM2008. Here, $h_{\text {ICESat }}$ is in meters in the EGM2008 datum while $\mathrm{h}_{\text {SRTM }}$ derived from the SRTM DEM, is the elevation in meters above EGM1996. The geoid height difference between EGM1996 and EGM2008 was computed following to Pavlis et al. (2008).

Each glacial elevation difference $\Delta \mathrm{h}$ depends on the characteristics of the terrain illuminated by the ICESat pulse and the characteristics of the ICESat measurement itself. Subsequently, a glacial elevation difference $\Delta \mathrm{h}$ is mointainod for firrthar $79^{\circ} 15^{\circ} 0^{\circ} 0^{\circ} 0^{\circ} \mathrm{E}$.

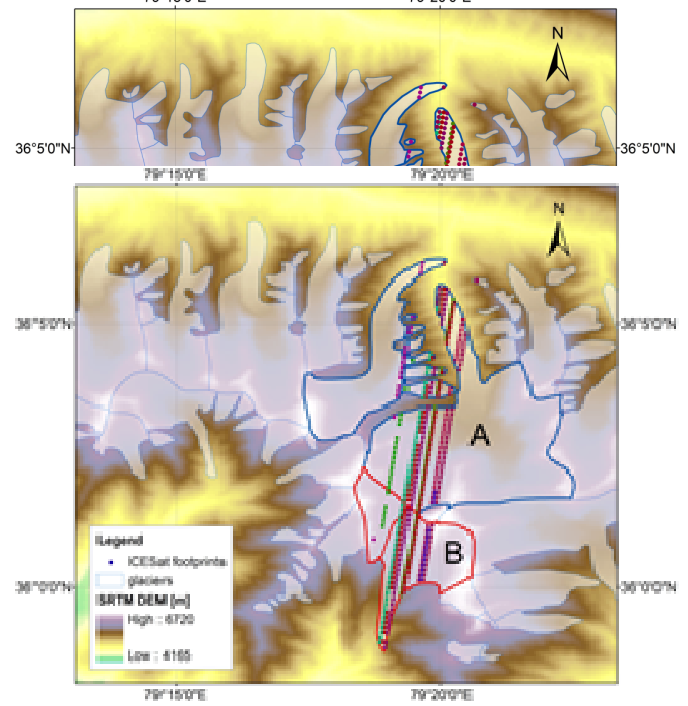

Figure 2. ICESat footprints superimposed over the GLIMS glacier mask. The ICESat-sampled glaciers having similar orientation were grouped into glacial areas A and B

\section{Trang B2}


c) Obtaining mean glacial elevation differences: For each sampled glacial area, glacial elevation differences all are timestamped by ICESat acquisition time. The ICESat acquisition time $t_{i}$ is defined per ICESat track segment, where one track is sampling a glacial area with consecutive individual footprints. A mean glacial elevation difference $\overline{\Delta h}_{i}$ is considered representative for the height of the glacial area above the SRTM base map at ICESat acquisition time $t_{i}$. In Figure 3 , the values $\overline{\Delta h}_{i}$ and $\mathrm{s}_{\mathrm{i}}$ representing mean glacial elevation differences and their standard deviations are shown between 2003 and 2009 for two glacial areas A and B.

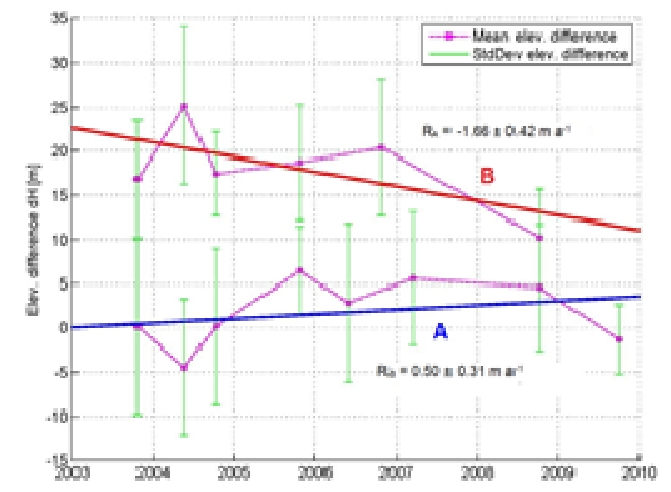

Figure 3. Distributions of the mean elevation differences and temporal glacial thickness change trends between 2003 and 2009 at the glacial areas A and $\mathrm{B}$

d) Estimating a temporal glacial thickness change trend: For each glacial area on the Tibetan Plateau, a temporal linear trend is estimated if there are at least six average differences or epochs available, corresponding to at least six ICESat campaign tracks during the observed period 2003 - 2009. An annual glacial thickness change trend is estimated by linear adjustment, following to Teunissen (2003). Note that $\mathrm{n}$ is required to be at least six epochs.
Subsequently, the rate $\mathrm{v}$ of a linear glacial thickness change and the propagated standard deviation $\sigma_{\mathrm{vv}}$ of the estimated velocity $\mathrm{v}$ are obtained. Additionally, the root mean square error (RMSE), as standard deviation of residuals, is also computed. This value consists of a combination of possible data errors and mainly the non-validity of the linear regression model.

Continuing to the example of Figure 3, glacial area A has an elevation decrease of -1.66 $\pm 0.42 \mathrm{~m} \mathrm{a}^{-1}$ and a RMSE of $3.46 \mathrm{~m}$ while glacial area $\mathrm{B}$ has an elevation increase of 0.50 $\pm 0.31 \mathrm{~m} \mathrm{a}^{-1}$ and a RMSE of $3.37 \mathrm{~m}$ between 2003 and 2009.

\section{RESULTS}

The result indicates that 90 glacial areas on the whole Tibetan Plateau are sampled by enough ICESat footprints to estimate thickness change. For each glacial area, a temporal trend in glacial thickness is estimated. In Figure 4, a glacial thickness change rate is symbolized by a red or blue disk at a representative location in each observed glacial area. Most of the observed glacial areas in the Himalaya, the Hengduan Mountains and the Tanggula Mountains experienced a serious decrease in glacial thickness. However, in most of the observed glacial areas in the western Kunlun Mountains in the north-west of the Tibetan Plateau, glaciers oriented toward the North were thickening while those oriented toward the South were thinning. In general, glacial thickness on the whole Tibetan Plateau decreased between 2003 and 2009 at a mean rate of $-0.17 \pm 0.47 \mathrm{~m} \mathrm{a}^{-1}$. This number is obtained by averaging all estimated rates $\mathrm{v}$ and their propagated standard deviations $\sigma_{\mathrm{vv}}$, but note that the size, distribution and representativeness of the observed glacial areas are not taken into account. 


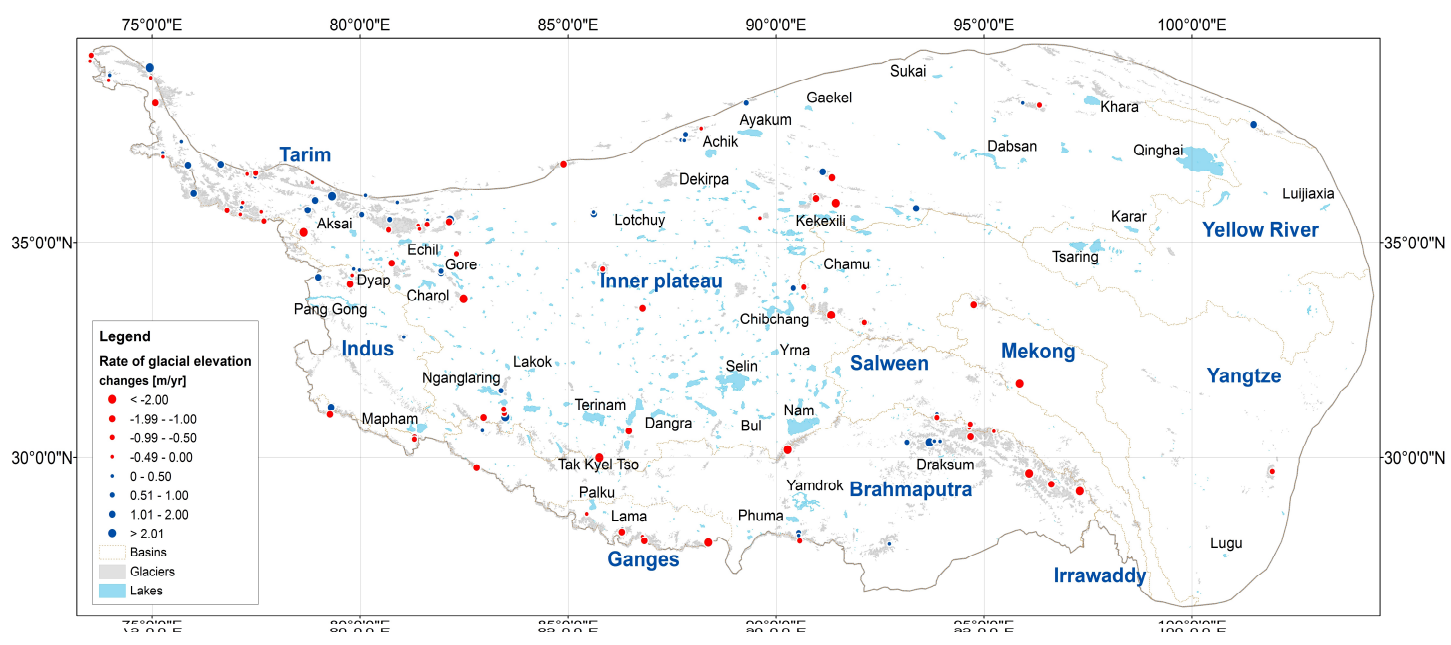

Figure 4: Glacial thickness change rates on the Tibetan Plateau between 2003 and 2009

Table 1. Mean glacial thickness change rates per mountain region on the Tibetan Plateau, compared to the results of Gardner et al. (2013).

\begin{tabular}{|l|r|r|}
\hline High mountain regions & $\bar{v}_{R} \pm \bar{\sigma}_{R}\left(\mathrm{~m} \mathrm{a}^{-1}\right)$ & $\begin{array}{r}\bar{v}_{G} \pm \bar{\sigma}_{G}\left(\mathrm{~m} \mathrm{a}^{-1}\right) \\
\text { (Gardner et al., 2013) }\end{array}$ \\
\hline The Himalaya range & $-0.81 \pm 0.46$ & $-0.53 \pm 0.13$ \\
\hline - Western & & $-0.44 \pm 0.20$ \\
\hline - Central & & $-0.89 \pm 0.13$ \\
\hline - Eastern & & $-0.40 \pm 0.41$ \\
\hline The Hengduan mountains & $-0.67 \pm 0.58$ & $0.02 \pm 0.14$ \\
\hline The western and inner plateau & $-0.05 \pm 0.45$ & $0.17 \pm 0.15$ \\
\hline The western Mt. Kunlun & $0.20 \pm 0.45$ & \\
\hline
\end{tabular}

Generally our results are comparable to elevation change rates $\bar{v}_{G} \pm \bar{\sigma}_{G}$ estimated for high-mountain Asian glaciers by Gardner et al. (2013). Both results indicate that most of the glaciers in the Tibetan Plateau are thinning, except for western Mt. Kunlun, as shown in Table 1. The strongest glacier-thinning occurs in the Himalaya range and in the Hengduan mountains. The glacial thickness change rate in the western and inner plateau is near balanced or nearly equals zero. Inversely glaciers in the western Mt. Kunlun are thickening.

\section{CONCLUSIONS}

By exploiting ICESat laser altimetry data, thickness change rates of 90 glacial areas on the whole Tibetan Plateau were estimated between 2003 and 2009. In this study, it is assumed that the settings of terrain slope and roughness equaling $20 \mathrm{deg}$ and $15 \mathrm{~m}$ to remove uncertain ICESat footprints, respectively, are appropriate for the steep and rough Tibetan Plateau. In addition, the orientation of glaciers has been taken into account. The study indicated that most of the observed glacial areas in the

\section{Trang B4}


Himalaya, the Hengduan Mountains and the Tanggula Mountains experienced a serious thinning while in most of the observed areas in the western Kunlun Mountains North-facing glaciers were thickening while South-facing glaciers were thinning.

\section{Giám sát biến đổi độ dày băng trên cao nguyên Tây Tạng từ dữ liệu ICESat}

- Phan Hiền Vũ ${ }^{1}$

- Roderik Lindenbergh ${ }^{2}$

- Massimo Menenti ${ }^{2}$

${ }^{1}$ Trường Đại học Bách Khoa, ĐHQG-HCM

${ }^{2}$ Trường Đại học Kỹ thuật Delft, Hà Lan

\section{TÓM TẮT}

Giám sát nhũng biến động về băng rất cần thiết cho việc đánh giá cân bằng nước của cao nguyên Tây Tạng. Nhũng nghiên cưu gần đây chỉ ra rằng các khối băng ở nhũng khu vực khác nhau trên cao nguyên Tây Tạng và khu vục xung quanh đang co lại và mỏng dần suốt các thập kỷ qua. Tuy nhiên, nhũng nghiên cứu này chỉ xem xét các khu vực lớn nên thwờng bỏ qua ảnh huởng của điè̀u kiện thời tiết và đặc điểm địa hình lên sư biến động của băng, ví dụ nhu ảnh huởng của luợng mưa và búc xa mặt trời. Do đó, giả thuyết của chúng tôi đặt ra rằng nhũng khối băng liền kề ở nhũng hướng ngược nhau biến động khác nhau. Trong nghiên cưu này, chúng tôi khai thác dũ liệu đo cao tù vệ tinh
ICESat kết hợp với mô hình độ cao số SRTM và mặt na băng GLIMS để vớc tính xu hwớng biến đổi độ dày băng giai đoạn 2003 - 2009 trên cao nguyên Tây Tạng. Kết quả chỉ ra rằng hầu hêt các khu vục băng trên cao nguyên Tây Tạng đang mỏng dần, ngoại trù một số khu vưc phía Tây Bắc của cao nguyên. Một cách khái quát, tốc độ mỏng dần trung bình của các khối băng trên toàn bộ cao nguyên là $0.17 \pm 0.47 \mathrm{~m} /$ năm trong giai đoạn 2003 - 2009, trung bình tốc độ biến đổi độ dày của 90 khu vục băng được giám sát. Ngoài ra, kết quả cũng chỉ ra rằng biến đổi về cao độ bề mặt băng phu thuộc rất nhiều vào vị trí tương đối của nó trên dải núi.

Tù khóa: cao nguyên Tây Tạng, biến đổi về băng, ICESat, SRTM, GLIMS.

\section{REFERENCES}

[1]. Bolch T, Yao T, Kang S, Buchroithner MF, Scherer D, Maussion F, Huintjes E, Schneider C. A glacier inventory for the western Nyainqentanglha Range and the
Nam Co Basin, Tibet, and glacier changes 1976 - 2009. The Cryosphere, 4, 419 - 433 (2010) 
[2]. Gardner AS, Moholdt G, Cogley JG, Wouters B, Arendt AA, Wahr J, Berthier E, Hock R, Pfeffer WT, Kaser G, Ligtenberg SRM, Bolch T, Sharp MJ, Hagen JO, van den Broeke MR, Paul F. A Reconciled Estimate of Glacier Contributions to Sea Level Rise: 2003 to 2009. Science, 340 (852), 857 - 857 (2013)

[3]. Jarvis A, Reuter HI, Nelson A, Guevara E. Hole-filled SRTM for the globe Version 4. The CGIAR-CSI SRTM 90m Database, (2008)

[4]. Kaab A, Berthier E, Nuth C, Gardelle J, Arnaud Y. Contrasting patterns of early twenty-first-century glacier mass change in the Himalayas. Nature, 488, 495 - 498 (2012)

[5]. Kropacek J, Neckel N, Bauder A. Estimation of volume changes of mountain glaciers from ICESat data: an example from the Aletsch Glacier, Swiss Alps. The Cryosphere Discussion, 7, 3261 - 3291 (2013)

[6]. Lay DC. Linear Algebra and its applications (3rd Edition). Addison Wesley, Chapter 6 (2002).

[7]. Li X (submitter). GLIMS Glacier Database. Boulder, Colorado USA: National Snow and Ice Data Center (2003)

[8]. Neckel N, Kropacek J, Bolch T, Hochschild V. Glacier mass changes on the Tibetan Plateau 2003-2009 derived from ICESat laser altimetry measurements. Environment Research Letters, 9, 2014.

[9]. Phan VH, Lindenbergh RC, Menenti M. ICESat derived elevation changes of Tibetan lakes between 2003 and 2009. International Journal of Applied Earth Observation and Geoinformatics, 17, 12 22 (2012)
[10].Quincey DJ, Luckman A, Benn D. Quantification of Everest region glacier velocities between 1992 and 2002, using satellite radar interferometry and feature tracking. Journal of Glaciology, 55 (192), 596 - 606 (2009).

[11].Shi Y, Liu C, Kang E. The glacier Inventory of China. Annals of Glaciology, 50 (53), 1 - 4 (2009)

[12].Sinnott RW. Virtues of the Haversine. Sky and Telescope, 68 (2), page 159 (1984).

[13].Sorg A, Bolch T, Stoffel M, Solomina O, Beniston M. Climate change impacts on glaciers and runoff in Tien Shan (Central Asia). Nature Climate Change, 2, 725 731 (2012)

[14].Teunissen PJG. Adjustment theory: an introduction. VSSD, Chapter 2 (2003).

[15]. Tian H, Yang T, Liu Q. Climate change and glacier area shrinkage in the Qilian mountains, China, from 1956 to 2010. Annals of Glaciology, 55 (66), 187 - 197 (2014).

[16]. Verdin KL, Godt JW, Funk C, Pedreros D, Worstell B, Verdin J. Development of a global slope dataset for estimation of landslide occurrence resulting from earthquakes. Colorado: U.S. Geological Survey, Open-File Report 2007 - 1188, (2007)

[17].Wang P, Li Z, Gao W. Rapid shrinking of glaciers in the Middle Qilian Mountain region of Northwest China during the last 50 years. Journal of Earth Science, 22, $539-548$ (2011)

[18]. Wei J, Liu S, Gou W, Yao X, Xu J, Bao W, Jiang Z. Surface-area changes of glaciers in the Tibetan Plateau interior area since the 1970s using recent Landsat images and 
historical maps. Annals of Glaciology, 55 (56), 213 - 222 (2014)

[19]. Yao T, Thompson L, Yang W, Yu W, Gao Y, Gou X, Yang X, Duan K, Zhao H, Xu $\mathrm{B}, \mathrm{Pu} \mathrm{J}, \mathrm{Lu} \mathrm{A}$, Xiang Y, Kattel DB, Joswiak D. Different glacier status with atmospheric circulations in Tibetan Plateau and surroundings. Nature Climate Change, 2, 663 - 667 (2012)

[20].Ye Q, Zhong Z, Kang S, Stein A, Wei Q, Liu J. Monitoring glacier and supraglacier lakes from space in Mt. Qomolangma Region of the Himalayas on the Tibetan plateau in China. Journal of Mountain and Science, 6, 211 - 220 (2009)
[21].Zandbergen P. Applications of Shuttle Radar Topography Mission Elevation Data. Geography Compass, 2 (5), 1404 1431 (2008)

[22].Zhang Y, Liu S, Xu J, Shangguan D. Glacier change and glacier runoff variation in the Tuotuo River basin, the source region of Yangtze River in western China. Environmental Geology, 56, 59 68 (2008)

[23].Zwally H, Schutz R, Bentley C, Bufton J, Herring T, Minster J, Spinhirne J, Thomas R. GLAS/ICESat L2 Global Land Surface Altimetry Data. Boulder, Colorado USA: National Snow and Ice Data Center (2011) 